\title{
Analisis Motivasi Belajar Matematika Siswa dalam Penerapan Edmodo di Masa Pandemi COVID-19
}

\author{
Zulia Alifia $^{1}$, Trisna Roy Pradipta ${ }^{2}$ \\ ${ }^{1,2}$ Program Studi Pendidikan Matematika, Fakultas Ilmu Pendidikan, Universitas Muhammadiyah Prof. Dr. HAMKA, \\ Jl. Tanah Merdeka No 20, Jakarta Timur, Indonesia \\ alifiazulia@gmail.com
}

\begin{abstract}
The COVID-19 virus outbreak has hit the entire world, including Indonesia. Policies for carrying out activities at home are issued such as online learning. This study aims to analyze the motivation of learning mathematics students in the application of Edmodo during the COVID-19 pandemic. The method used in this study is descriptive qualitative. The subjects used in this study were grade IX-F students at SMP Dharma Pertiwi Depok as many as 33 students. The instrument used is a motivational questionnaire to learn mathematics with 18 statements. The statement was used to determine the response from respondents regarding the motivation to learn mathematics in the application of Edmodo during the COVID-19 pandemic. The results showed that grade IX-F students have good motivation in mathematics learning using the Edmodo application with an average percentage of all indicators of $76.244 \%$. Also supported by the results of interviews with the homeroom teacher as well as math teacher grade IX-F. The conclusion of this study is that students have good motivation in learning mathematics based on Edmodo during the COVID-19 pandemic.
\end{abstract}

Keywords: Analysis, motivation of learning, Edmodo, mathematics

\begin{abstract}
Abstrak
Wabah virus COVID-19 telah menyerang seluruh dunia, termasuk Indonesia. Kebijakan untuk melakukan kegiatan dirumah pun dikeluarkan termasuk pembelajaran daring. Penelitian ini bertujuan untuk menganalisis motivasi belajar matematika siswa dalam penerapan Edmodo di masa pandemi COVID-19. Metode yang digunakan dalam penelitian ini adalah kualitatif deskriptif. Subjek yang digunakan dalam penelitina ini adalah siswa kelas IX-F di SMP Dharma Pertiwi Depok sebanyak 33 siswa. Instrumen yang digunakan yaitu angket motivasi belajar matematika dengan 18 pernyataan. Pernyataan tersebut digunakan untuk mengetahui tanggapan dari responden terkait motivasi belajar matematika dalam penerapan Edmodo dimasa pandemi COVID-19. Hasil dari penelitian menunjukan bahwa siswa kelas IX-F memiliki motivasi baik dalam pembelajaran matematika menggunakan aplikasi Edmodo dengan perolehan rata-rata presentase dari semua indikator sebesar 76,244\% . Didukung juga oleh hasil wawancara kepada wali kelas sekaligus guru matematika kelas IX-F. Kesimpulan dari penelitian ini adalah siswa memiliki motivasi baik dalam pembelajaran matematika berbasis Edmodo di masa pandemi COVID-19.
\end{abstract}

Kata kunci: Analisis, motivasi belajar, Edmodo, matematika

Copyright (c) 2021 Zulia Alifia, Trisna Roy Pradipta

Corresponding author: Zulia Alifia

Email Address: alifiazulia@gmail.com (Jl. Tanah Merdeka No 20, Jakarta Timur, Indonesia)

Received 03 April 2021, Accepted 16 April 2021, Published 16 April 2021

\section{PENDAHULUAN}

Wabah virus corona virus disease atau biasa dikenal dengan covid-19 telah menyerang seluruh penjuru dunia. Salah satu Negara yang terkena wabah ini adalah Indonesia. Banyak aktivitas-aktivitas yang harus dihentikan agar tidak memakan banyak korban. Wabah ini telah menjadi tantangan bagi lembaga pendidikan. Untuk mengantisipasi terjadinya penyebaran yang semakin meluas, lembaga pendidikan dan lembaga pemerintahanpun mengeluarkan berbagai kebijakan seperti physical distancing, aturan untuk memakai masker hingga dilaksanakannya PSBB. Kebijakan tersebut mengharuskan warga Indonesia untuk tetap berada dirumah. Pemerintah memberikan beberapa himbauan. Himbauan tersebut adalah merubah tatap muka menjadi daring (Rahman, 2020). 
Semua aktivitas yang biasa dilakukan di luar, sekarang harus dilakukan di dalam rumah. Aktivitas yang dilakukan dirumah seperti belajar, bekerja bahkan beribadahpun harus dilaksanakan di dalam rumah. Siswa diharuskan untuk belajar di dalam rumah. Terhitung sudah hampir memasuki bulan ke-4 siswa belajar di dalam rumah. Para gurupun dituntut untuk menggunakan model pembelajaran yang sesuai dengan kondisi sekarang ini. Pemerintah menganjurkan pelaksanaan pembelajaran baik tingkat SD, SMP, SMA, dan perguruan tinggi untuk melakukan pembelajara secara online.

Di masa pandemi seperti sekarang ini membuat keberadaan teknologi sangat diperlukan dalam penunjang aktivitas sehari-hari terutama dibidang pendidikan. Pembelajaran daring merupakan satusatunya solusi agar tidak terjadinya perkumpulan dalam suatu ruangan yang dapat mempermudah penyebaran virus. Dikondisi seperti ini, para guru dituntut untuk terbiasa dengan teknologi, agar para siswa tetap mendapatkan haknya dalam belajar. Disaat yang mendesak seperti ini, para guru harus membuat rancangan pembelajaran dari awal kembali. Rancangan yang dibuat harus menyesuaikan dengan keadaan seperti sekarang (Warmi et al., 2020)

Salah satu mata pelajaran yang terdampak dalam penerapan pembelajaran daring adalah matematika. Matematika merupakan induk dari segala ilmu pengetahuan. BSNP (BSNP, 2006) menyatakan bahwa jika ingin menguasai sekaligus menciptakan teknologi dimasa mendatang maka diperlukannya penguasaan terhadap matematika sedini mungkin.

Matematika perlu sekali diajarkan kepada peserta didik karena matematika akan selalu digunakan di kehidupan sehari-hari. Sehingga matematika ditetapkan sebagai salah satu mata pelajaran yang dijadikan sebagai mata pelajaran wajib diajarkan disetiap jenjang mulai dari SD sederajat, SMP sederajat, SMA sederajat maupun perguruan tinggi. Pembelajaran matematika yang sering terjadi di kelas hanya bersifat penjelasan materi. Dengan hanya penjelasan materi, siswa dituntut untuk mengolah informasi dan menelaah konsep yang diberikan oleh guru. Sehingga menghalangi daya abstraksi peserta didik. Matematika dianggap sulit dan membosankan, banyak siswa yang gagal dalam pelajaran matematika di tahun pertama pendidikan formal (Bishara, 2018).

Hal yang sangat penting dimasa pandemi seperti sekarang adalah motivasi belajar siswa. Motivasi untuk belajar merupakan proses yang direncanakan dan diarahkan secara konsisten untuk mencapai solusi tertentu (Bishara, 2016). Pada pandemi COVID-19 ini, siswa merasakan kesulitan dalam mempelajarai matematika dan juga kejenuhan yang dirasakan oleh siswa. Motivasi belajar adalah sebuah proses yang membangkitkan, mengarahkan, dan melestarikan kebiasaan masyarakat terhadap tujuan pembelajaran tertentu karena itu mencerminkan faktor-faktor yang mendorong seseorang untuk berprilaku dengan cara tertentu (Bishara, 2018).

Motivasi belajar sangatlah penting bagi seluruh anak di setiap umur dan tingkatan. Motivasi terbagi menjadi dua yaitu motivasi intrinstik dan ekstrinstik (Bishara, 2018). Penelitian yang dilakukan dari perspektif behavioris menunjukan bahwa kesuksesan dalam matematika terdapat pengaruh dari motivasi untuk mencapai presetasi (Atit et al., 2020). Motivasi intrinstik adalah motivasi yang timbul dalam diri siswa yang biasanya tidak membutuhkan dorongan dari faktor luar. Siswa yang baik motivasi 
intrinstiknya biasanya memiliki tekad yang baik dalam mendapatkan hasil belajar yang terbaik (Warmi et al., 2020). Motivasi ekstrinstik adalah motivasi yang ditimbulkan dengan adanya dorongan dari luar dan harus didukung dengan lingkungan belajar yang baik. Maksudnya adalah jika kondisi lingkungan belajarnya baik maka siswapun akan belajar dengan baik. Motivasi seseorang dapat diukur dari motifnya (Cleopatra, 2015). Pada masa pandemic COVID-19, terdapat satu indikator yang berbeda, yaiatu efikasi diri. Menurut Elliot dkk dalam (Kurniyawati, 2012) salah satu faktor yang mempengaruhi motivasi belajar siswa.

Di masa pandemi seperti sekarang, sistem pendidikan didunia rata-rata menggunakan sistem pembelajaran daring (e-learning) terutama Indonesia. Pemerintah Indonesia mengeluarkan kebijakan untuk melakukan segala kegiatan sekolah secara daring atau menggunakan sistem e-learning. Kebijakan tersebut tertuang pada (Nasional, 2020). Pembelajaran dengan sistem e-learning membutuhkan dukungan-dukungan seperti laptop, handphone, dan tablet yang dapat didukung oleh akses internet dimana saja dan kapan saja.

E-learning merupakan salah satu sistem pembelajaran yang menggunakan media elektronik. Dengan menggunakan sistem pembelajaran e-learning, guru tidak perlu menyampaikan materi secara langsung atau tatap muka melainkan guru dapat memberikan materi pembelajaran dengan menggunakan media elektronik. Siswa tidak perlu belajar didalam kelas, tetapi siswa dapat belajar dimana saja dan kapan saja asalkan tetap terhubung dengan internet.

Salah satu platform yang dapat digunakan untuk mendukung e-learning adalah Edmodo. Edmodo dibuat oleh Nic Borg dan Jeff O'Hara pada tahun 2008 untuk instruktur, murid, orang tua, sekolah, dan wilayah (Ma'azi \& Janfeshan, 2018). Nic dan Jeff merasa bahwa diperlukannya pengembangan lingkungan sekolah untuk terpenuhinya hubungan keterkaitan di era abad 21. Edmodo adalah platform pembelajaran yang gratis dan aman digunakan yang menyediakan pengajaran dan dapat mengelola kelas secara online dan memungkinkan akan terhubung dengan peserta didik dimanapun dan kapanpun (Putranti, 2013).

\section{METODE}

Penelitian ini dilakukan untuk mendeskripsikan motivasi belajar matematika siswa dalam penerapan Edmodo di masa pandemic covid-19. Metode penelitian yang digunakan dalam penelitian ini adalah metode kualitatif dengan jenis penelitian deskriptif. Subjek yang digunakan adalah siswa kelas IX-F di SMP Dharma Pertiwi Depok sebanyak 33 orang. Penelitian ini dilakukan pada bulan Februari 2021. Untuk mengukur motivasi belajar siswa dalam pembelajaran matematika berbasis Edmodo di masa pandemic siswa diberi angket skala sikap yang teridir dari pertanyaan positif dan negatif sebanyak 18 butir pertanyaan dan peneliti melakukan wawancara kepada guru. Angket yang digunakan menggunakan skala likert dengan 4 (pilihan). Peneliti tidak menyediakan pilihan "ragu-ragu" agar jawaban responden lebih terarah. Untuk penyebaran angket, peneliti menggunakan platform Sparrow karena tampilannya yang menarik dan mudah untuk di akses oleh responden. 
Tabel 1. Kriteria penilaian skala Likert Angket Motivasi Belajar Matematika

\begin{tabular}{|c|c|}
\hline Pilihan Jawaban & Skor \\
\hline Sangat Setuju & 4 \\
\hline Setuju & 3 \\
\hline Tidak Setuju & 2 \\
\hline Sangat Tidak Setuju & 1 \\
\hline
\end{tabular}

(Sukardi, 2019)

Analisis data dilakukan dengan memberikan skor pada pilihan siswa, lalu di akumulasikan per indikator untuk mendapatkan besar presentasenya. Kemudian dianalisis dan disesuaikan dengan kategori termasuk baik atau tidakkah motivasi belajar siswa menggunakan aplikasi Edmodo Kategori penilaian dapat dilihat dari tabel berikut:

Tabel 2. Kategori Tabel dalam Presentase

\begin{tabular}{|c|c|}
\hline Kategori & Aspek Penilaian \\
\hline $0-20$ & Kurang Sekali \\
\hline $21-40$ & Kurang \\
\hline $41-60$ & Cukup \\
\hline $61-80$ & Baik \\
\hline $81-100$ & Baik Sekali \\
\hline
\end{tabular}

(Widoyoko, 2019)

Metode wawancara yang digunakan peneliti adalah wawancara semistruktur karena dalam melakukan wawancara peneliti menananyakan beberapa pertanyaan yang sudah di terstruktur kemudian satu persatu pertanyaan diperdalam untuk mendapatkan keterangan lebih lanjut. Tujuan wawancara ini adalah peneliti ingin mendapatkan pernyataan lebih terbuka dari peserta didik tentang pembelajaran melalui Edmodo di masa pandemi COVID-19.

\section{HASIL DAN DISKUSI}

Analisis data dilakukan untuk mengkonversi data skala dengan mengacu pada (Widoyoko, 2019). Kategori didapatkan dengan cara menghitung tiap-tiap skor pada indikator lalu mengubah data kuantitatif (penilaian) menjadi data kualitatif (kategori penilaian).

Data hasil motivasi belajar matematika diperoleh dari hasil angket dengan indikator sebagai berikut: 1) Adanya minat dalam belajaar, 2) Adanya keinginan untuk mendapat nilai yang bagus, 3) Adanya dukungan dari orang tua, 4) Tekun dalam belajar, 5) Disiplin dalam belajar, 6) Adanya rasa tanggung jawab, 7) Efikasi diri.

Setelah melakukan penelitian di SMP Dharma Pertiwi Depok, peneliti mengubah bentuk data yang sudah didapatkan ke bentuk interval lalu diklasifikasikan berdasarkan kategori presentase skalanya. Berikut adalah hasil angket yang telah diolah dan disajikan dalam penjelasan berikut:

\section{Indikator Adanya Minat dalam Belajar}

Indikator adanya minat dalam belajar memiliki 4 sub indikator, diantaranya : kemauan belajar matematika dengan menggunakan fitur yang ada di aplikasi Edmodo, niat untuk terlibat, berpartisipasi dan memperhatikan pembelajaran matematika, kemauan dalam memperhatikan materi matematika, dan 
ketertarikan dalam proses pembelajaran matematika.

Pada sub indikator kemauan belajar matematika dengan menggunakan fitur yang ada di aplikasi Edmodo memperoleh nilai presentase sebesar 69,697\% dan masuk kedalam kategori motivasi baik. Untuk sub indikator niat untuk terlibat, berpartisipasi dan memperhatikan pembelajaran matematika memperoleh nilai presentase sebesar 77,273\% dan masuk kedalam kategori motivasi baik. Untuk sub indikator kemauan dalam memperahatikan materi matematika memperoleh nilai presentase sebesar $82,576 \%$ dan masuk kedalam kategori motivasi baik sekali. Untuk sub indikator ketertarikan dalam proses pembelajaran matematika memperoleh presentase $71,970 \%$ dan masuk kedalam kategori baik. Untuk indikator 1 dapat disimpulkan siswa memiliki minat dalam belajar matematika karena memperoleh nilai rata-rata sebesar 75,378\%.

\section{Indikator Adanya Keinginan dalam Mendapat Nilai yang Bagus}

Indikator adanya keinginan dapat mendapat nilai bagus memperoleh presentase sebesar $87,121 \%$ dan masuk kedalam kategori motivasi baik sekali. Siswa berlomba-lomba untuk mendapatkan nilai matematika yang bagus walaupun belajar dilakukan secara daring menggunakan aplikasi Edmodo di masa pandemi COVID-19.

Indikator

\section{Indikator Adanya Dukungan dari Orang Tua}

Adanya dukungan dari orang tua membuat siswa memiliki motivasi yang baik. Dilihat dair perolehan presentasenya sebesar 77,273\% dan masuk kedalam kategori motivasi baik.

\section{Indikator Tekun dalam Belajar}

Indikator tekun dalamm belajar memiliki 2 sub indikator yaitu mengikuti pembelajaran matematika dengan baik dan aktif selama pembelajaran matematika. Siswa yang mengikuti pembelajaran matematika dengan baik memiliki motivasi yang baik. Dilihat dari presentase yang diperoleh sebesar 80,3030\% dan masuk kedalam kategori motivasi baik sekali. Untuk sub indikator aktif selama pembelajaran matematika memperoleh presentase sebesar $62,878 \%$ dan masuk kedalalm kategori motivasi baik. Dapat disimpulkan untuk indikator tekun dalam belajar matematika siswa memiliki motivasi baik dengan rata-rata presentasenya $71,591 \%$.

\section{Indikator Disiplin dalam Belajar}

Indikator disiplin dalam belajar memiliki 3 sub indikator yaitu disiplin mengikuti pembelajaran matematika, selalu mengikuti proses pembelajaran matematika, dan selalu bergabung di aplikasi Edmodo tepat waktu. Siswa tetap disiplin mengikuti pembelajaran matematika walaupun guru tidak memberi materi memiliki motivasi baik. Dapat dilihat dari nilai presentasenya yaitu $71,970 \%$ dan masuk kedalam kategori motivasi baik. Untuk sub indikator selalu mengikuti proses pembelajaran matematika memperoleh presentase sebesar 78,030\% dan masuk kedalam kategori motivasi baik. Untuk sub indikator siswa selalu bergabung di aplikasi Edmodo tepat waktu termasuk kedalam kategori motivasi baik dengan perolehan presentase sebesar 70,454\%. Dapat disimpullkan indikator disiplin dalam belajar, siswa memiliki motivasi baik dengan perolehan rata-rata presentase sebesar 73,485\%. 


\section{Indikator Adanya Rasa Tanggung Jawab}

Siswa merasa tugas matematika yang diberikan oleh guru merupakan suatu tanggung jawabnya. Siswa memiliki rasa tanggung jawab terhadap tugas yang tinggi dilihat dari presentase yang diperoleh sebesar 85,606\% dan masuk kedalam kategori motivasi baik. Untuk sub indikator siswa merasa membantu teman yang tidak mengerti terkait materi pelajaran matematika merupakan suatu tanggung jawab. Siswa membantu teman yang tidak mengerti terkait materi melakukan diskusi melalui chat. Siswa yang mengerti terkait materi menjelaskan melalui voice note atau video call. Nilai presentase yang diperoleh adalah 71,212\% dan termasuk kedalam kategori motivasi baik.

\section{Indikator Efikasi Diri}

Indikator efikasi diri memiliki 5 indikator. Indikator tersebut terdiri dari menjelaskan hasil yang telah diperoleh kepada guru dan siswa lain, mengingat materi dengan baik, memahami materi yang telah diajarkan. mengulang materi yang telah diajarkan, menyimpulkan materi yang telah berlangsung.

Efikasi diri matematika erat kaitannya dengan konsep diri matematika (Bagaka's, 2011). Efikasi diri juga menandakan keyakinan seseorang bahwa dia mampu untuk melaksanakan dengan sukses suatu perilaku untuk menghasilkan hasil tertentu (Opseth et al., 2017). Siswa yag memiliki efikasi diri tinggi Kepercayaan diri siswa dalam menjelaskan hasil yang siswa dapatkan memperoleh presentase sebesar 63,636\% dan termasuk kedalam kategori motivasi baik. Untuk sub indikator siswa dapat mengingat materi dengan baik memperoleh presentase sebesar 71,212\% termasuk kedalam kategori motivasi baik. Untuk sub indikator siswa dapat memahami materi yang terlah diajarkan memperoleh presentase sebesar $72,727 \%$ dan termasuk kedalam kategori motivasi baik. Siswa diminta untuk mengulang materi yang telah diajarkan oleh guru memperoleh presentase sebesar 73,485\% dan termasuk kedalam kategori motivasi baik. Untuk sub yang terakhir yaitu siswa diberikan kesempatan untuk menyimpulkan materi yang telah diajarkan menimbulkan motivasi yang baik. Diperoleh dari hasil presentasenya sebesar $73,385 \%$ yang termasuk kedalam kategori motivasi baik.

Dari semua indikator yang telah diporeleh, maka dapat disimpulkan dengan tabel sebagai berikut:

Tabel 3. Hasil Angket Siswa Terkait Motivasi Belajar Matematika Siswa dalam Penerapan Edmodo

\begin{tabular}{|c|c|c|c|c|}
\hline No & Indikator & Skor & $\%$ & Kategori \\
\hline 1 & $\begin{array}{lll}\text { Adanya } & \text { Minat dalam } \\
\text { Belajar } & & \\
\end{array}$ & 398 & 75,378 & Baik \\
\hline 2 & $\begin{array}{l}\text { Adanya Keinginan } \\
\text { Mendapatkan Nilai yang } \\
\text { Bagus }\end{array}$ & 115 & 87,121 & Baik Sekali \\
\hline 3 & $\begin{array}{ll}\text { Adanya } & \text { Dukungan } \\
\text { Orang Tua } & \end{array}$ & 102 & 77,273 & Baik \\
\hline 4 & Tekun dalam Belajar & 189 & 71,591 & Baik \\
\hline 5 & Disiplin dalam Belajar & 291 & 73,485 & Baik \\
\hline 6 & $\begin{array}{l}\text { Adanya Rasa Tanggung } \\
\text { Jawab }\end{array}$ & 207 & 78,409 & Baik \\
\hline
\end{tabular}




\begin{tabular}{|l|c|c|c|c|}
\hline 7 & Efikasi Diri & 465 & 70,454 & Baik \\
\hline \multicolumn{2}{|c|}{ Jumlah } & 1767 & 76,244 & Baik \\
\hline
\end{tabular}

Berikut bentuk grafiknya:

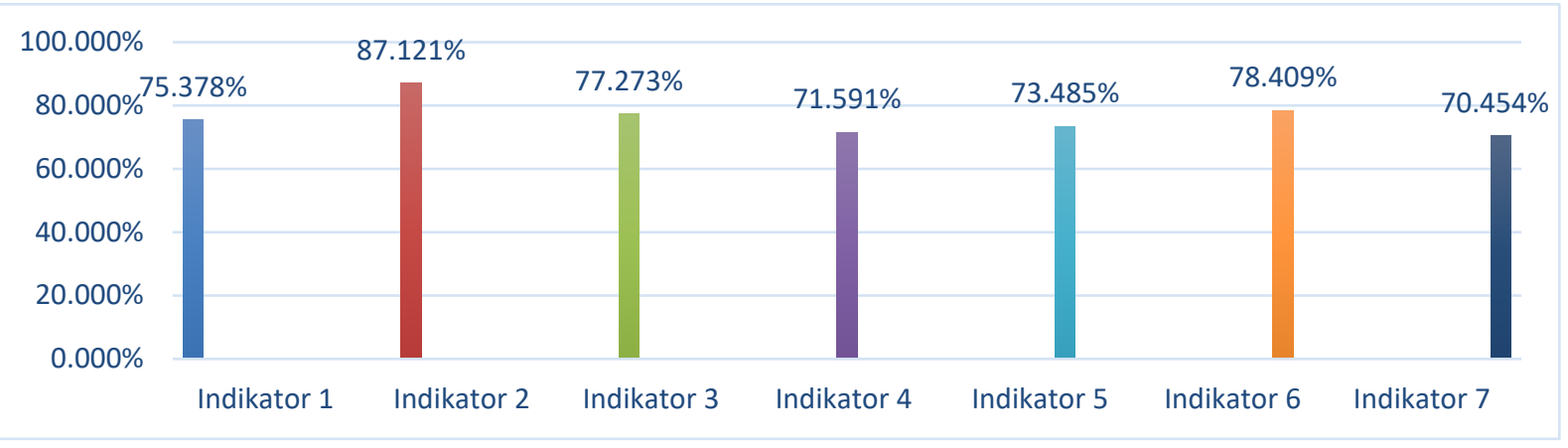

Gambar 1. Presentase Motivasi Belajar Matematika Siswa

\section{Keterangan}

Indikator 1: Adanya minat dalam belajar

Indikator 2: Adanya keinginan mendapat nilai yang bagus

Indikator 3: Adanya dukungan orang tua

Indikator 4: Tekun dalam belajar

Indikator 5: Disiplin dalam belajar

Indikator 6: Adanya rasa tanggung jawab

Indikator 7: Efikasi Diri

Diagram diatas menunjukan bahwa siswa memiliki motivasi baik terhadap minat dalam belajar. Terlihat dari presentase yang dihasilkan sebesar 75,378\%. Motivasi baik sekali terhadap keinginan dalam mendapatkan nilai yang bagus dengan memperoleh presentase sebesar $87,121 \%$. Adanya dukungan orang tua dalam pelaksanaan pembelajaran matematika menyebabkan siswa memiliki motivasi baik yang ditunjukan oleh presentasi nilai sebesar 77,273\%. Tekun dalam belajar menunjukan motivasi baik dengan presentase sebesar $71,591 \%$. Motivasi baik ditunjukan siswa pada indikator disiplin dalam belajar dengan memperoleh presentase sebesar 73,485\%. Adanya rasat tanggunng jawab dalam pembelajaran matematika menyebabkan siswa memiliki motivasi baik dengan memperoleh presentase $78,409 \%$. Pada indikator efikasi diri, siswa memiliki motivasi baik dengan besar presentase $70,454 \%$.

Didukung oleh hasil wawancara kepada guru matematika yang juga wali kelas kelas IX-F. Guru hanya menggunakan beberapa fitur yang ada didalam aplikasi Edmodo. Selain itu, siswa memperhatikan dengan baik penjelasan materi yang disampaikan oleh guru selama pembelajaran matematika berlangsung. Faktor dari luar yaitu dukungan dari orang tua juga sangat berpengaruh dalam proses pembelajaran matematika. Banyak orang tua yang mendukung siswa terhadap pembelajaran matematika di masa pandemi COVID-19. 


\section{KESIMPULAN}

Dari uraian diatas dapat disimpulkan bahwa siswa kelas IX-F di SMP Dharma Pertiwi Depok di masa pandemi COVID-19 memiliki motivasi baik dalam pembelajaran matematika berbasis Edmodo dilihat dari perolehan rata-rata nilai seluruh indikator sebesar 76,244\%. Dapat dilihat juga dari perolehan nilai presentase setiap indikatornya yang termasuk kedalam kategori baik dan baik sekali. Didukung oleh hasil wawancara dengan wali kelas yang juga guru matematika kelas IX-F. Bagi peneliti berikutnya, sebaiknya juga memfokuskan penelitian terhadap motivasi ekstirinsik belajar siswa. Motivasi ekstrinsik juga mempengaruh pada motivasi belajar matematika siswa.

\section{REFERENSI}

Atit, K., Power, J. R., Veurink, N., Uttal, D. H., Sorby, S., Panther, G., Msall, C., Fiorella, L., \& Carr, M. (2020). Examining the role of spatial skills and mathematics motivation on middle school mathematics achievement. International Journal of STEM Education, 7(1). https://doi.org/10.1186/s40594-020-00234-3

Bagaka's, J. G. (2011). The role of teacher characteristics and practices on upper secondary school students' mathematics self-efficacy in Nyanza province of Kenya: A multilevel analysis. International Journal of Science and Mathematics Education, 9(4), 817-842. https://doi.org/10.1007/s10763-010-9226-3

Bishara, S. (2016). Creativity in unique problem-solving in mathematics and its influence on motivation for learning. Cogent Education, 3(1). https://doi.org/10.1080/2331186X.2016.1202604

Bishara, S. (2018). Active and traditional teaching, self-image, and motivation in learning math among pupils with learning disabilities. Cogent Education, 5(1). https://doi.org/10.1080/2331186X.2018.1436123

BSNP. (2006). Standar Kompetendi dan Dasar Kompetensi SMP/MTs. In Standar Isi Untuk Standar Pendidikan Dasar dan Menengah (p. 139).

Cleopatra, M. (2015). Pengaruh Gaya Hidup dan Motivasi Belajar terhadap Prestasi Belajar Matematika. Formatif: Jurnal Ilmiah Pendidikan MIPA, 5(2), 168-181. https://doi.org/10.30998/formatif.v5i2.336

Kurniyawati, R. (2012). Hubungan Antara Efikasi Diri dengan Motivasi Belajar Siswa. Universitas Muhammadiyah Surakarta.

Ma'azi, H., \& Janfeshan, K. (2018). The effect of Edmodo social learning network on Iranian EFL learners writing skill. Cogent Education, 5(1), 1-17. https://doi.org/10.1080/2331186X.2018.1536312

Nasional, U. (2020). C. d. 0.0075 300. 300.

Opseth, T. M., Carstensen, T., Yazdani, F., Ellingham, B., Thørrisen, M. M., \& Bonsaksen, T. (2017). Self-efficacy for therapeutic mode use among occupational therapy students in Norway. Cogent Education, 4(1). https://doi.org/10.1080/2331186X.2017.1406630

Putranti, N. (2013). Cara Membuat Media Pembelajaran Online. Jurnal Pendidikan Informatika Dan Sains, 2(2), 139-147.

Rahman, S. R. (2020). Pembelajaran Online di Tengah Pandemi Covid-19. 02(02), 81-89.

Sukardi, P. H. M. (2019). Metodologi Penelitian Pendidikan. Jakarta: Bumi Aksara. 
Warmi, A., Adirakasiwi, A. G., Santoso, E., Karawang, U. S., Majalengka, U., Siswa, K. B., \& Daring, P. (2020). MOTIVASI DAN KEMANDIRIAN BELAJAR SISWA PADA MATA PELAJARAN MATEMATIKA DI MASA PANDEMI COVID-19 ( STUDI PADA SISWA KELAS VII SMPN 3 KARAWANG TAHUN. 8(3), 197-202.

Widoyoko, E. P. (2019). Evaluasi Program Pembelajaran. Yogyakarta: Pustaka Pelajar. 